\title{
RAS Superfamily Protein
}

National Cancer Institute

\section{Source}

National Cancer Institute. RAS Superfamily Protein. NCI Thesaurus. Code C18549.

Small cellular monomeric proteins with GT Pase activity, RAS Superfamily Proteins are involved in signal transduction in normal cellular growth, differentiation, and development. 